\title{
Finding an Easier Way to Explain the Statement of Cash Flows
}

\author{
Seung Hwan Kim \\ Associate Professor \\ Alabama State University, USA \\ E-mail: skim@alasu.edu
}

Received: July 30, 2021

Accepted: August 24, 2021

Published: August 30, 2021

doi: 10.5296/ijafr.v11i3.18892

URL: https://doi.org/10.5296/ijafr.v11i3.18892

\begin{abstract}
The statement of cash flows is one of the required financial statements of public companies, and thus is required of all accounting majors. After learning the other required financial statements in an introductory financial accounting course and, again, in the first intermediate accounting course, accounting majors learn how to prepare the statement of cash flows in the second or last intermediate accounting course. Most accounting majors find the statement of cash flows significantly more difficult to learn than any other financial statements. Especially, students find it most difficult to understand the indirect method of preparing the statement of cash flows. Preparing the statement of cash flows using the indirect method, students go through the most difficult time, specifically, doing the adjustments that are made to net income to reconcile to cash flows from operating activities.

In this paper, presented is a different way to explain the principles of indirect method of preparing the statement of cash flows with a focus on the reconciliation of net income to cash flows from operating activities. Different from the explanations in the textbooks available in the market, the approach presented in the paper is preferred by all the students who were taught the statement of cash flows. Also, pointed out in the paper are a few things that students are easily confused of in learning the statement of cash flows.
\end{abstract}

Keywords: Statement of cash flows, Indirect method, Adjustments, Reconciliation, Confusion points 


\section{Introduction}

Historically and currently, accounting is one of the popular majors in college of business of any university or college. Demand for accounting majors in the job market seems constant whether the economy is in good shape or in not-so-good shape. Some say, when the economy is good, of course, accounting majors are well demanded, and, when the economy is not so good, demand for accounting majors is still good because there are many business combinations, such as mergers and acquisitions, that occur as ways for companies to survive or adapt to unfavorable economic situations. Every business combination takes huge amount of accounting service, which then leads to demand for accountants.

Unless accounting majors pass CPA (certified public accounts) exam or other professional exams in accounting, their competence as accounting majors is shown by their grades on major accounting courses they took at their respective schools. It is reported not rarely that there are accounting graduates who meet minimum GPA (grade point average) requirement of job applicants, yet lack basic accounting knowledge, and cannot carry out an entry level accounting task. Among the basic accounting knowledge, there are basic and required financial statements of public companies. One of the required financial statements is the statement of cash flows, which students learn the full details of in a later intermediate accounting course, although students are briefly exposed to the statement of cash flows in an introductory financial accounting course. The importance and value of learning the statement of cash flows cannot be over-emphasized because it is required of all accounting majors whichever school they attend. However, it is easily observed that many students in the intermediate accounting course struggle with the chapter where the statement of cash flows is covered and move on leaving significant portion of it not understood, particularly, indirect method of preparing the statement.

For years of teaching the statement of cash flows, the author has tried a few ways to explain the indirect method of preparing the statement of cash flows, and has found one way that is simpler and easier for students to understand how to prepare the statement of cash flows by the indirect method. Presented in the paper is a different approach from those in the textbooks available in the market. Also, presented are a few points that are found most confusing to students in learning the statement of cash flows.

This paper consists of six sections hereafter: 'literature review' followed by 'significance of the issue,' 'purpose of the paper,' 'a new approach to explaining the indirect method,' 'open-ended test of principles of indirect method,' and 'conclusions, suggestions, and limitations.'

\section{Literature Review}

After reviews of researches on the competence of current accounting majors and accounting graduates, concluded is that nearly all the relevant researches on this subject assumed that passing students in any accounting course know what they are supposed to. No researches are found yet that questioned whether or not the passing students in an accounting course know what they are supposed to, or the basics of the course at the minimum. 
In reality, it is not rare to find graduating accounting students who cannot complete the accounting cycle and cannot prepare the basic financial statements (income statement, statement of retained earnings, and balance sheet), not to mention the statement of cash flows which is most complex among them. More serious of the current issue is that some instructors who teach the statement of cash flows don't seem to have a solid understanding of the statement, regurgitate the textbook illustrations without explaining the principles of the indirect method, in particular, the adjustments to net income, or even skip the chapter of the statement of cash flows in its entirety.

Although not much found in the researches so far, there are a number of testimonials from students that the statement of cash flows is one of two most difficult topics to grasp in financial accounting, the other topic being the consolidation of financial statements in an advanced financial accounting course. Then, it would be justifiable to warrant a new pedagogical approach to better explaining the statement of cash flows.

A limited number of researches can be found that address the lack of understanding of the statement of cash flows; so, the author's relevant personal teaching experience of the issue at multiple schools is utilized, together with the limited number of researches relevant to this specific topic. The students whom the author taught the statement of cash flows are from the years, 2012 to 2020, at a state-supported university in the Northeast and at a state-supported university in the South. The teaching experience of the topic reflected in the paper is from four years at each of the schools, and the students are well diversified. Next is the summary of the literature related to the paper.

Most other research papers in the topic presented different approaches to better instruction of the statement of cash flows without any doubt of the validity of either method. However, Drtina and Largay III (1985) casted doubt on the validity of indirect method. They demonstrated "how the indirect method will in fact not equal actual cash flow from operations because of numerous conceptual and practical problems encountered when applying the necessary adjustments." They showed "how cash flow from operations calculated by the indirect method is, at best, an estimate of actual cash provided by operations," and illustrated the problems of the adjustments.

After the validity issue of indirect method, in search of new pedagogical approaches to the statement of cash flows, one of early researches on this topic was done by Dugan et al. (1991). In their paper, they utilized a few different modular approaches to enhance students' understanding of the concepts and rules underlying the cash-flows statement. Additionally, they explained the timing difference between accrual basis of accounting and cash basis of accounting when calculating the net cash flows from operating activities under indirect method. More than ten years later, there came another alternative approach to the illustrations used in common financial accounting textbooks from Brickner and McCombs (2004). They used journal entries and T-accounts in explaining the statement of cash flows under the indirect method.

Another decade later, different yet interesting findings on instructional approaches to the cash-flows statement came from McNellis (2015). Although most prominent intermediate 


\section{Mll Macrothink}

International Journal of Accounting and Financial Reporting

ISSN 2162-3082

2021, Vol. 11, No. 3

financial accounting textbooks cover the statement of cash flows (SCF) in one chapter towards the end of textbook, which is called a massed presentation, he argued that "the SCF is a topic that is cross-sectional in nature, and is applicable to the textbook material on the accounting transactions that are spread throughout the texts." He found "instruction of SCF material across the major (skipped) chapters, a spaced presentation format, potentially yields enhanced learning outcomes in comparison to the massed presentation."

In a few years after McNellis, an intuitive approach to the instruction of cash-flows statement was researched by Stice et al. (2019). In their approach, they illustrated a process by which they analyzed income statement and balance sheet in order to present the information in the section of cash flows from operating activities under either direct or indirect method. They said their process was to allow students to apply an intuitive approach in computing the cash flows from operation activities rather than memorizing the mechanical rules for each method.

\section{Significance of the Issue}

Comparing the statement of cash flows to the other required financial statements, the other financial statements are introduced in the introductory financial accounting course in good detail, and repeated in the first intermediate accounting course in full detail. Thus, students have the second chance to clear any confusion left from the prerequisite course, and stabilize and reinforce their understanding of the three financial statements. On the contrary, the cash-flows statement is first covered in the second or last intermediate accounting course, having no chance to be revisited thereafter. Even worse, the cash-flows statement is usually covered in the course close to the end of semester when students are much exhausted following up the class and going towards the end of semester.

Looking at the fixed structure of cash-flows statement which consists of three sections (cash flows from operating activities, cash flows from investing activities, and cash flows from financing activities), students have little struggle learning the direct method of preparing the cash-flows statement because it is so straightforward. However, the direct method of the cash-flows statement itself is very rarely tested on any accounting professional exams wherever financial statements are tested. Most of questions on the cash-flows statement that are asked on accounting professional exams are of indirect method. Under the indirect method, it is the first section of the statement, cash flows from operating activities, that so many students lose their grip on the statement of cash flows and are forced to move on only being able to prepare part of the cash-flows statement, but not knowing how to complete the cash-flows statement and see the statement work.

\section{Purpose of the Paper}

It is not surprising but rather common and easy to find undergraduate and master-level accounting majors who cannot prepare a typical cash-flows statement using the indirect method. Many a student say 'reading the chapter in a textbook helps but doesn't get them to completely understand how the indirect-method cash-flows statement works.' Other students say, 'reading the chapter more often gets them more confused.' Students complain further 
that there are so many pages in the chapter showing a variety of examples, but they still don't get the essential idea of how it works.

In an effort to find a better way to explain the cash-flows statement by the indirect method, for the past several years, the author has tried on students a few slightly different approaches from different textbooks while teaching the course, and one approach has been found the best, which means 'easiest,' for students to understand the principles of indirect method. For the indirect method, students always had difficulty understanding adjustments to net income, which is the first section of the statement. The author realized that the main reason for the difficulty understanding the adjustments is because students try to understand all the adjustments and interactions among them at once; in other words, they try to juggle all the adjustments up in the air.

The different point of the approach of the paper is that each adjustment is assumed to be the only one with nothing else related to it. Explaining one adjustment alone is the simplest way for the instructor, and juggling one adjustment only is the easiest for students. After all the adjustments, students see this piece-by-piece adjustment approach work the whole system of cash-flows statement. Traditional approaches in the textbooks explain the adjustments one by one. But, they do not use one-adjustment-alone assumption, leaving students in the piles of adjustments somewhere they are lost.

In the following section, illustrations of the new approach are presented along the structure of cash-flows statement and, where applicable, common confusion points are presented as well.

\section{A New Approach to Explaining the Indirect Method}

When students are shown two statements of cash flows of one company: one prepared by the direct method and the other by the indirect method. The students find soon that, except the first section, cash flows from operating activities, the rest two sections of the statement is exactly the same like 'copy and paste' from each other. At the beginning of statement, students see cash flows from operating activities by the indirect method start with net income from income statement and see come next adjustments to reconcile net income to net cash provided (used) by operating activities.

\section{Confusion Point 1:}

All the students know net income from income statement is not necessarily cash net income because income statement is prepared on an accrual basis. But, many students think it takes adjustments that reconcile only non-cash income-statement items to a cash basis, hope that it work, but never see it work. The first confusion derives from the wrong assumption that the adjustments to net income are only for income-statement items. It is explained that there are not only income-statement item adjustments but also balance-sheet item adjustments and that the adjustments just start with net income and take whatever it takes in order to make it work. As quick examples for balance-sheet item adjustments, shown are accounts receivables that are from prior periods but collected in cash in the current period, and accounts payables that are accrued in prior periods but paid in cash in the current period, both of which are well known to students as balance-sheet accounts. 


\section{Macrothink \\ International Journal of Accounting and Financial Reporting \\ ISSN 2162-3082 \\ 2021, Vol. 11, No. 3}

\section{Filling Out the Statement of Cash Flows from the End}

When preparing the statement of cash flows, the usual information given are comparative balance sheets for the prior and current period, income statement, and additional information given in words. Given the format of cash-flows statement, starting to fill out the blank statement from the beginning is not suggested, but actually suggested is to start filling out the blank statement from the end. This is because the last three lines are the easiest ones to find the answers for from the information given. They are as follows:

3. Net change in cash difference between beginning and ending cash $(=\# 1-\# 2)$

2. Cash, beginning cash balance from balance sheet of prior period

1. Cash, ending cash balance from balance sheet of current period

Next is to fill out the third section of the statement, cash flows from financing activities, because this section has the items that are most simple and straightforward, and the items listed under this section are limited to the following ones:

- + Issuance of stocks

- - Purchase of treasury stocks

- $\quad+$ Issuance of bonds (notes)

- - Redemption of bonds (notes)

- - Payment of dividends

The next easiest section to fill out is the second section, cash flows from investing activities. This middle section has two kinds of items listed under it, sale or purchase of investment items, as follows:

- $\quad+$ Sale of property, plant, and equipment

- - Purchase of property, plant, and equipment

- - Purchase of investment stocks and bonds

- + Sale of investment stocks and bonds

\section{Confusion Point 2:}

Technically speaking, it is understandable to take it as a rule that the whole cash received from sale of property, plant, and equipment (PPE) or from sale of investment stocks and bonds should be listed in this section including gains or losses resulting from the sales. But, when beginning and ending PPE balances are compared to compute the amount that the PPE is sold for in the period, the difference between these two balances is a book value not including a gain or loss from the sale; however, most of students report this amount as the real price that the PPE is sold for including a gain or loss. Likewise, absolute majority of students compare beginning and ending balances of investment stocks and bonds on comparative balance sheets, get the difference of the two numbers, and think that is the real 
price that the investment stocks and bonds are sold for including a gain or loss, which is not true, either.

This confusion is probably because it is easy to say what item for what amount should be reported in this section, but it is not easy to remember and calculate the real price of PPE or investment stocks/bonds sold because it takes information from across financial statements.

\section{What to Do Last and What to Remind}

It is suggested to students to do the first section, cash flows from operating activities, last because it is the most complicated and time-consuming section. Before starting to do this first section, which will finish up the statement of cash flows, as said in Confusion Point 1, "the adjustments just start with net income and take whatever it takes in order to make it work," it is reminded that everything else that doesn't pertain to financing or investing activities should be adjusted here in the first section, and that this is the logic and reason why it is suggested to do the first section last. Also, said to students is that, when using the direct method, if any item doesn't belong to financing or investing activities, it should be listed under cash flows from operating activities. So, students are reminded of the same principle across the indirect and direct method that, unless an item falls under cash flows from financing or investing activities, it falls under cash flows from operating activities.

Because the adjustments to net income can go long on the list, and some of them are related to each other, it would be better off to start the adjustments with a set of assumptions that are technically correct and practically easier to work with. The assumptions used throughout the first section of cash-flows statement are explained next.

\section{Assumptions Used, Not New but Made Clear}

In the first section of cash-flows statement, cash flows from operating activities, after beginning with net income that comes straight from income statement, students have the biggest struggle with the adjustments that come right after net income. When students see the long list of adjustments thereunder, they look scared and confused wondering how all the adjustments come into play and work out the cash-flows statement. Some smart students look more confused wondering how such related accounts as inventory, accounts payable, cost of goods sold, etc. work one another out, and work the cash-flows statement out. Then, the following three assumptions are given to students as an approach to explaining the indirect method.

\section{Assumption 1:}

First, go through income statement, and assume each account on income statement is a cash transaction if it can be a cash transaction.

\section{Assumption 2:}

When any income-statement account is not a cash transaction, it is reflected in the related balance-sheet account, then, adjust the balance-sheet account. If this is not understood, assume it is exactly true because it is. 
Assumption 3:

Imagine the simplest transaction possible for each account, and assume that is the only transaction for the whole period for the whole company. In other words, when looking at one account, assume all the other accounts don't exist unless necessary.

When students are told these three assumptions, they look understanding and ready to proceed. So, a series of typical adjustments are explained to them according to the assumptions. Examples of the typical adjustments are illustrated next.

\section{Illustrations}

\section{$\underline{\text { Sales Revenue }}$}

Starting with income statement as said in Assumption 1, the first one on income statement, sales revenue is assumed to be a cash transaction for now. As in Assumption 2, if the sales revenue is not a cash transaction, it is reflected in accounts receivable as an increase by the amount of sales revenue, and the increase in accounts receivable is adjusted as a subtraction from net income because that sales revenue is turned out to be not cash at the end. As in Assumption 3, the simplest sales revenue transaction is assumed; that is, the whole amount of sales revenue is a cash sale or credit sale, and, when it is a credit sale, accounts receivable is necessary to record it. Students said, assuming this is the only transaction for the whole period for the whole company, they are clear on how to make an adjustment for the increase in accounts receivable.

As to decrease in accounts receivable, beginning accounts-receivable balance is from a non-cash sale in a previous period per Assumptions 1 and 2, and, per Assumption 3, it is assumed that this is the only transaction for the whole period for the whole company. Then, students are sure that simple decrease in accounts receivable should be adjusted as an addition to cash flows from operating activities, although it looks added to net income, because cash is collected (increased) as much as the decrease in accounts receivable.

\section{Cost of Goods Sold}

By Assumption 1, it is assumed that the goods (inventory) sold is bought in cash in the current period. By Assumption 2, if it is not a cash transaction, it is recorded in the related balance-sheet account, accounts payable. Then, for the increase in accounts payable, accounts payable should be adjusted as an addition because it turns out that cash is not paid for the increase in accounts payable. By Assumption 3, assuming that this is the simplest and only transaction for the whole company for the whole period, students say all clear so far.

As to decrease in accounts payable, beginning accounts-payable balance is from a non-cash purchase in a previous period per Assumption 2, skipping Assumption 1, and, per Assumption 3, it is assumed that this is the only transaction for the whole company for the whole period. Then, students keep up with that simple decrease in accounts payable should be adjusted as a subtraction from cash flows from operating activities, although it looks subtracted from net income, because cash is paid (decreased) as much as the decrease in accounts payable. By this time, it seems a certain number of students who have nothing 
confused this far are developing a sense of the principles of how adjustments would go for other receivable or payable accounts.

Keep going on income statement, after sales revenue and cost of goods sold, comes gross profit. It is a small confusion that some students consider gross profit to be an income-statement account for which an adjustment should be made. In order to clear this confusion, it is explained that gross profit is just a subtotal of the previous accounts, not an independent account, and that no adjustment is necessary for a non-independent account.

\section{Depreciation Expense}

In regards to Assumptions 1 and 2, depreciation expense cannot be a cash transaction, the related balance-sheet account, accumulated depreciation, is recorded to keep up the total depreciation expense that has been accumulated to date, and accumulated-depreciation account is not anything to be sold for or collected in cash. Then, according to Assumption 3, if this depreciation is the only transaction for the whole period for the whole company, the depreciation expense causes net loss for the amount of depreciation expense. But, there is no change in cash because the depreciation expense is a non-cash expense; therefore, the depreciation expense should be added back to cancel out the net loss, resulting in no change in cash overall. Students take on the adjustment for depreciation expense easier than the other ones thus far, and, from this time on, students look like going down the hill in catching the principles that work behind the adjustments.

It is a breeze for students to go through other income-statement accounts like the ones below, find their related balance-sheet accounts, and make the adjustments the same way as cost of goods sold vs. accounts payable, using the three assumptions:

- Salaries expense $\rightarrow$ Salaries payable

- Interest expense $\rightarrow$ Interest payable

- $\quad$ Taxes expense $\rightarrow$ Taxes payable

Gain or Loss from Sale of Property, Plant, and Equipment, or from Investment Stocks/Bonds

After clearing Confusion Point 2, students understand the gain from sale of assets of investment nature is already included in cash flows from investing activities, and that the gain is net income, assuming that is the only transaction, Assumption 3. Thus, students comprehend why the gain should be subtracted from cash flows from operating activities, because, otherwise, the gain is double counted, once in cash flows from investing activities, and the second time in cash flows from operating activities.

After gone through income-statement accounts, the rest of adjustments are made for the remaining accounts on comparative balance sheets and for additional information. Common adjustments are as follows: 


\section{Macrothink \\ International Journal of Accounting and Financial Reporting \\ ISSN 2162-3082 \\ 2021, Vol. 11, No. 3}

Accounts Receivable

Done at the time of sales revenue

Inventory

Increase in inventory is assumed to be purchased in cash in this period (Assumption 1 and then Assumption 2 skipped), and, assuming it is that simple and only transaction (Assumption 3), it is adjusted as a subtraction from cash flows from operating activities, although it looks like it is subtracted from net income.

Decrease in inventory is assumed to be that the inventory bought in a previous period (then Assumptions 1 and 2 skipped) is sold in the current period and that this is the only and simple transaction (Assumption 3). This decrease in inventory shows up as cost of goods sold on income statement, but this cost of goods sold is already paid in cash in the previous period, or its related balance-sheet account, accounts payable, is adjusted in the previous period when this inventory was bought. So, now this cost of goods sold on income statement is not a cost of cash and is added back to net income to reconcile to a cash basis.

\section{Prepaid Insurance}

Similar to but simpler than inventory, increase in prepaid insurance is assumed to be purchased in cash in this period (Assumption 1 and then Assumption 2 skipped), and, assuming it is the one simple transaction (Assumption 3), it is adjusted as a subtraction from cash flows from operating activities.

Decrease in prepaid insurance is assumed that the prepaid insurance bought in a previous period (then Assumptions 1 and 2 skipped) is expensed in the current period and that this is the only transaction (Assumption 3). This decrease in prepaid insurance shows up as insurance expense on income statement, but this insurance expense is already paid in cash in the previous period. So, now this insurance expense on income statement is not a cost of cash and is added back to net income to reconcile to a cash basis.

Doing the adjustments so far in this order, after a few adjustments for the current assets on comparative balance sheets, usually there are not many adjustments left to do because adjustments are already made for long-term assets (property, plant, and equipment), liabilities (payables), and stocks in cash flows from their respective activities. It is almost the end of adjustment list leaving one account, retained-earnings.

\section{Confusion Point 3:}

When students get to retained-earnings account in stockholders' equity section, they look lost having no idea on how to make an adjustment for this account. And, when students look at the cash-flows statement that is done up to this point, they see the total of cash flows from the three activities is equal to net change in cash, which then seems everything on the statement works out without any adjustment for retained earnings. Students wonder whether this is a coincidence or not. When students are told it is all done and that they should not do anything to retained earnings all the time, they are happily surprised and ask why. 


\section{MInstitute ${ }^{\text {Mink }}$}

International Journal of Accounting and Financial Reporting

ISSN 2162-3082

Few students really understand the explanation for this question that is stated in any text book. So, the author's explanation is provided in the following steps;

- Between beginning and ending retained-earnings balance, there are only two items: plus net income (or minus net loss) and minus dividend.

- Net income is the summary of individual income-statement accounts.

- For net income, all the individual income-statement accounts are adjusted back to net income as necessary.

- For a dividend, it is already listed in cash flows from financing activities.

- A dividend account behaves like an expense account, normal debit balance and closed to retained earnings. It works through the three assumptions like any expense account.

- Because both the two contents of retained earnings are already reconciled individually to a cash basis, no more adjustment is left to do.

After students are reminded that cash-flows statement proves how beginning cash balance changes to ending balance for the period and that all the source accounts themselves are adjusted as they affect cash balance, students don't seem to have any hassle clearing this third confusion point and getting through the whole cash-flows statement.

\section{Open-Ended Test of Principles of Indirect Method}

Because the adjustments illustrated in the paper are only for typical examples, and so the adjustments are open ended, leaving other adjustments possible and necessary in other cases, students are tested if they can handle the adjustments for some other similar accounts to those shown. This test is to confirm whether students have learned the principles of the adjustments, or they just have memorized only the examples shown. To do this test, students are given several other accounts with their beginning and ending balances and asked to do the adjustments for the accounts; they are amortization expense, wages payable, supplies, dividends income, dividends receivable, and notes payable.

After students are first given reviews on how these accounts are journalized for what transactions, a large number of them sound confident to tell how to do the adjustments for these new accounts. This result is pretty much the same as that on a regular exam later on.

\section{Conclusions, Suggestions, and Limitations}

Since a long time ago, students have been complaining that accounting textbooks are so expensive that often times the cost of a textbook for an accounting course is higher that the tuition of the course. Besides, students complain there is too much information beyond what they need to learn in such many pages in every chapter. Students say each chapter is like an encyclopedia or dictionary on the topic of the chapter, and they say they want to read a textbook that is written concisely and helps them understand every chapter efficiently. As a way to come up with an explanation for the cash-flows statement to this end, the approach 


\section{Mll Macrothink}

International Journal of Accounting and Financial Reporting

ISSN 2162-3082

2021, Vol. 11, No. 3

presented in the paper is a little different from those in the textbooks, clinically tested on students for several years, and found to be significantly easier for students to learn the indirect method of cash-flows statement.

It is suggested that the statement of cash flows be taught in the beginning of term in order that students can exert fresh efforts to learn this important but not so easy material.

Lastly, it is to be noted this study has its limitations. Although empirical data is necessary to support the approach presented in the paper worked better for students than conventional textbook approaches, it was unfeasible to conduct controlled experiments to get quantitative data. The main reason was there had been only one section of the course every semester when the author was assigned the course to teach. It would take multiple sections of the course in one semester to make the comparisons across the sections where different pedagogical approaches are utilized, respectively. So, it is acknowledged that this paper is based on the author's perception from his teaching experience.

\section{References}

Brickner, D. R., \& McCombs, G. B. (2004). Teaching the Indirect Method of the Statement of Cash Flows in Introductory Financial Accounting: A Comprehensive, Problem-Based Approach. Journal of Education for Business, 80(1), 41-46.

Drtina, R. E., \& Largay III, J. A. (1985). Pitfalls in Calculating Cash Flow from Operations. Accounting Review, 314-326.

Dugan, M. T., Gup, B. E., \& Samson, W. D. (1991). Teaching the Statement of Cash Flows. Journal of Accounting Education, 9(1), 33-52.

Gordon, E. A., Ready, J. S., \& Sannella, A. J. (2018). Intermediate Accounting. New York, NY: Pearson.

Hanlon, M. L., Hodder, L., Nelson, K. K., Roulstone, D., \& Dragoo, A. L. (2019). Intermediate Accounting. Westmont, IL: Cambridge Business Publishers.

Kieso, D. E., Weygandt, J. J., \& Warfield, T. D. (2019). Intermediate Accounting. Hoboken, NJ: Wiley.

McNellis, C. J. (2015). Re-Conceptualizing Instruction on the Statement of Cash Flows: The Impact of Different Teaching Methods on Intermediate Accounting Students' Learning. Advances in Accounting Education: Teaching and Curriculum Innovations, 17, 115-144.

Miller-Nobles, T. L. (2017). Horngren's Accounting. New York, NY: Pearson.

Spiceland, D., Nelson, M., Thomas, W. \& Sepe, J. (2020). Intermediate Accounting. New York, NY: McGraw-Hill Education.

Stice, J. D., Stice, E. K., Cottrell, D. M., \& Stice, D. (2019). Teaching Operating Cash Flow: One Matrix for Analysis - Two Methods for Presentation. Advances in Accounting Education: Teaching and Curriculum Innovations, 22, 199-215. 


\section{Macrothink \\ International Journal of Accounting and Financial Reporting ISSN 2162-3082}

Wahlen, J. M., Jones, J. P., \& Pagach, D. P. (2019). Intermediate Accounting: Reporting and Analysis. Boston, MA: Cengage Learning.

\section{Copyright Disclaimer}

Copyright for this article is retained by the author(s), with first publication rights granted to the journal.

This is an open-access article distributed under the terms and conditions of the Creative Commons Attribution license (http://creativecommons.org/licenses/by/4.0/) 